\title{
PHYTOCHEMICAL ANALYSIS AND ANTIOXIDANT ACTIVITY OF THE HYDROETHANOLIC EXTRACT OF PASSIFLORA EDULIS \\ F. FLAVICARPA RESIDUES
}

\author{
JUSSIMARA BARROS DE OLIVEIRA* \\ JORGE VITÓRIO GOMES DAS NEVES** \\ MARCONDES VIANA DA SILVA ${ }^{* * *}$
}

\begin{abstract}
Most fruit residues are known for being rich in bioactive phytochemicals such as polyphenols (natural antioxidants), responsible for major health benefits when consumed regularly due to their role in the prevention of degenerative diseases. The objective of this study was to determine the phytochemical composition (condensed tannins, total flavonoids, and total phenolic content) and evaluate the antioxidant capacity (DPPH and ABTS assays) of the flour prepared from yellow passion fruit residues, composed of epicarp and mesocarp, generated by fruit pulp processing industries. Passion fruit residues were subjected to heat treatment in an oven with renewal and air circulation and processed into flour. The phytochemical composition results revealed the following: condensed tannins, $0.31 \mathrm{mg} .100 \mathrm{~g}^{-1}$; total flavonoids, $23.87 \mathrm{mg} 100 \mathrm{~g}^{-1}$; and total phenolic content, $24.87 \mathrm{mg}^{1} 100 \mathrm{~g}^{-1}$. The DPPH assay showed that yellow passion fruit residue flour has a significant antioxidant activity, and there was a positive correlation between antioxidant activity and the total phenolic content according to the ABTS assay and the DPPH radical scavenging method. Passion fruit residue flour is a source of natural antioxidants with potential to be used in the food industry as an ingredient in the development of food products with functional claims.
\end{abstract}

* Master in Food Engineering, Study Center Food Science, University of Southwest Bahia (UESB), Itapetinga, Bahia, Brazil (e-mail: marah_disc@hotmail.com)

** Master's student in Engineering and Food Science, UESB, Itapetinga, Bahia, Brazil (e-mail: jorgevitorioneves@ gmail.com)

*** Doctorate in Food Science and Technology, Department of Exact and Natural Sciences, UESB, Itapetinga, Bahia, Brazil (e-mail: mviana@hotmail.com) 


\section{INTRODUCTION}

The agro-industrial production of fruit pulp generates large amount of residue. This issue has been addressed in some studies that focus on the recovery of fruit residues with the preparation of dehydrated residue flour (NAGEL et al., 2014; DHILLON, KAUR and BRAR, 2013; ABUD and NARAIN, 2009).

The use of by-products from fruit pulp processing industries to produce residue flours is an alternative to reduce environmental impact related to the improper disposal of this kind of residue.

Brazil stands out as the largest producer of passion fruit, accounting for about $90 \%$ of total world production. In 2012 its production totaled 776,090 tons with an average yield of $13.42 \mathrm{t} / \mathrm{ha}$ in an estimated an area of 57.84 thousand hectares. The Northeast region is responsible for $77.67 \%$ of this production, and the state of Bahia is the largest producer, followed by the states of Ceará and Sergipe (EMBRAPA, 2014).

The yellow passion fruit (Passiflora edulis f. flavicarpa), native to tropical America, is the most cultivated and most important species of passion fruit in Brazil. The national production exceeds that of lemon and melon, and it is primarily intended for the production of juice (MELETTI, 2011; OLIVEIRA et al., 2002). Passion fruit basically consists of an epicarp, mesocarp (white part), fleshy arillus, endocarp or pulp, and seeds. Its peel represents about $60 \%$ of the total fruit weight and can be used in animal feed and in human food (OLIVEIRA et al., 2002).

Among other substances, passion fruits have phenolic compounds (ZERAIK and YARIWAKE, 2010; KOBORI and JORGE, 2005), phytomolecules that have been subject of extensive research due to their functional claims. Among the main countries that have been investing in research on polyphenols are the United States, Spain, Italy, China, and Brazil (HAMINIUK et al., 2012).

Recent studies have indicated antioxidant activity and the presence of bioactive phytochemicals in yellow passion fruit. Studying passion fruits, Zeraik et al. (2010) found that most of the substances present in the peel and pulp of this fruit can contribute to beneficial health effects, such as antioxidant activity, anti-hypertension, and lower blood glucose and cholesterol levels. They also found that the commercial species of passion fruit are sources of alkaloids, flavonoids, carotenoids, minerals, provitamin A, and vitamin C, substances responsible for the functional effect in foods.

Evaluating the proximate composition and antioxidant activity of dehydrated passion fruit seed extract, Jorge et al. (2009) observed that this agro-industrial residue generated after juice extraction has antioxidant activity, and therefore it can be used as a natural alternative to produce food products.

Therefore, further studies on the characterization of agro-industrial residues to evaluate the potential of fruit by-products as sources of bioactive phytochemicals in the food industry are necessary.

The objective of this study was to determine the phytochemical composition (condensed tannins, total flavonoids, and total phenolic content) and evaluate the antioxidant capacity (DPPH and ABTS assays) of the flour prepared from yellow passion fruit residues generated by fruit pulp processing industries.

\section{MATERIALS AND METHODS}

The yellow passion fruit residues used in this study were kindly provided by the pulp processing industries Frutar and Nutrical, located in the municipalities of Vitoria da Conquista and Ibirataia, Bahia, respectively. Ten kg of residue were collected in three different periods, between November 2011 and April 2012, totaling $30 \mathrm{~kg}$ of agro-industrial residue.

The passion fruit residues collected were placed in plastic bags and stored under the 
temperature of $-18\left( \pm 2{ }^{\circ} \mathrm{C}\right)$. In the preparation step, the passion fruit by-products were selected and only the epicarp and the mesocarp were used. The fruit residues were thoroughly washed in running water to remove traces of dirt and were immersed in a solution containing $50 \mathrm{ppm}$ of available chlorine for 15 minutes (EMBRAPA, 2011). They were then manually cut into smaller pieces (approximately 6 $\mathrm{cm}^{2}$ ) to facilitate the grinding and drying processes.

The residues were dried in an oven with renewal and air circulation under temperature of $60\left( \pm 2{ }^{\circ} \mathrm{C}\right)$ for 48 hours, conditions necessary to achieve the desired water content of approximately $10 \%$. Subsequently, the residues were stored in a desiccator for two hours. During the grinding process, the residues were initially Wiley-milled and then processed using a household blender (properly cleaned and sanitized) to reduce particle size. An 80-mesh sieve was used to standardize the particle size of the flour, and the product obtained was packed in polyethylene containers with lid and maintained at $-18\left( \pm 2{ }^{\circ} \mathrm{C}\right)$ until analysis.

The phytochemical composition of passion fruit residue flour was determined based on the estimated levels of condensed tannin (proanthocyanidins), total flavonoids, and phenolic compounds. The analyses were performed in triplicate, and the results expressed as mean \pm standard deviation.

\subsection{DETERMINATION OF TOTAL FLAVONOID CONTENT}

Total flavonoid content was determined according to the method of Woisky and Salatino (1998) using aluminum chloride. The extracts were prepared with $0.5 \mathrm{~g}$ of the sample diluted in $50 \mathrm{ml}$ of an ethanol/water $\left(80: 20 \mathrm{v} \cdot \mathrm{v}^{-1}\right)$ solution and placed into an ultrasound bath for 20 minutes, as suggested by Marinova, Ribarova and Atanassova (2005). All absorbance measurements were performed at $445 \mathrm{~nm}$ using a spectrophotometer. Total flavonoid content was quantified as equivalent of quercetin over a concentration range of 0.005 and 0.100 $\mathrm{mg} \cdot \mathrm{mL}^{-1}$, and a calibration curve was produced $\left(\mathrm{R}^{2}=0.909\right)$. The result was expressed as $\mathrm{mg}$ of quercetin. $100 \mathrm{~g}^{-1}$ dry weight.

\subsection{DETERMINATION OF CONDENSED TANNINS CONTENT}

Condensed tannins (proanthocyanidins) content was determined using the acid-butanol assay, according to the method described by Porter, Hrstich and Chan (1986). This method is based on acid catalyzed oxidative depolymerization of condensed tannins into anthocyanidins. All absorbance measurements were performed at $550 \mathrm{~nm}$ using a spectrophotometer. The condensed tannins (CT) content was expressed as mg catechin. $100 \mathrm{~g}^{-1}$ dry weight using the following equation: $\mathrm{TC}=$ (reading of the sample at $550 \mathrm{~nm} \times 78.26 \times$ dilution factor $) /(\%$ dry matter).

\subsection{DETERMINATION OF TOTAL PHENOLIC CONTENT}

The ethanolic extract was obtained according to the procedure proposed by Zhao and Hall (2008), and the sample was homogenized with hydroethanol solution $\left(80: 20{\mathrm{v} . \mathrm{v}^{-1}}^{-1}\right.$.

The determination of total phenolic content was performed according to the procedure proposed by Wettasinghe and Shahidi (1999) using the Folin-Ciocalteu reagent (FCR). It was measured using a gallic acid standard curve over a concentration range of 0.001 and $0.040 \mathrm{mg}^{-1} \mathrm{ml}^{-1}$ and linear regression $\left(R^{2}=0.998\right)$. The results were expressed as $\mathrm{mg}$ gallic acid. $100 \mathrm{~g}^{-1} \mathrm{dry}$ weight. All absorbance measurements were performed at $773 \mathrm{~nm}$ using a spectrophotometer. Based on the total phenolic content results, the antioxidant capacity was evaluated using the DPPH and ABTS radical scavenging methods.

\subsection{DETERMINATION OF ANTIOXIDANT CAPACITY BY DPPH RADICAL METHOD}


DPPH free radical scavenging activity was determined according to the modified method proposed by Brand-Willians, Cuvelier and Berset (1995). This method is based on the reduction of $\mathrm{DPPH}^{\bullet}$ (2,2-diphenyl-1-picryl-hydrazyl), a phenolic antioxidant present in the sample, resulting in a decrease in absorbance, measured at $517 \mathrm{~nm}$. The activity of free radicals was calculated using the following equation:

$$
\mathrm{I} \%=\frac{A b s_{0}-A b s_{1}}{A b s_{0}} \times 100
$$

Where: $1 \%=$ percentage inhibition; $A b s_{0}=$ Absorbance of the control reaction; $A b s_{1}=$ Absorbance of the extract at different concentrations.

\subsection{DETERMINATION OF ANTIOXIDANT CAPACITY BY ABTS RADICAL METHOD}

The determination of the antioxidant capacity using the 2.2'-Azino-bis-(3ethylbenzthiazoline-6-sulfonic acid) (ABTS) was performed according to the method described by $\operatorname{Re}$ et al. (1999). The ABTS ${ }^{*+}$ was generated by the reaction of a $7 \mathrm{mM}$ aqueous solution of ABTS with $2.45 \mathrm{mM}$ potassium persulphate. This solution was maintained in the dark at room temperature for 16 hours. Subsequently, the ABTS ${ }^{\bullet+}$ solution was diluted in ethanol to a final absorbance of $0.7 \pm 0.05$ to $734 \mathrm{~nm}$.

The hydroethanolic extracts with different total phenolic concentrations ( 0.02 to $0.1 \mathrm{mg} \cdot \mathrm{mL}^{-1}$ ) obtained according to the procedure proposed by Zhao and Hall (2008) were added to the ABTS*+ solution, and the absorbance was measured using a spectrophotometer at $734 \mathrm{~nm}$ after reaction for $6 \mathrm{~min}$. The antioxidant capacity of the sample was calculated based on the ascorbic acid activity under the same conditions. The results were expressed as ascorbic acid equivalent antioxidant capacity (mg VEAC.g-1 dry weight).

\section{RESULTS AND DISCUSSION}

Under the conditions used in this study, the passion fruit residue flour produced a yield of $9.67 \%( \pm 2.01)$ in relation to the content in raw material (Table 1). This result can be attributed to losses during processing such as handling, milling, sieving, and water loss.

TABLE 1 - YIELD OF YELLOW PASSION FRUIT RESIDUE FLOUR

Yield

Passion fruit residue flour

$9.67 \pm 2.01$

${ }^{1}$ mean \pm standard deviation.

With regard to the average levels of phytochemicals present in the passion fruit residue flour (Table 2), it can be observed that the flavonoids had $23.87 \mathrm{mg}^{-1}$ quercetin. $100 \mathrm{~g} \mathrm{mg}^{-1}$ dry weight. Cohen et al. (2008) analyzed the functional compounds present in the pulp of the fruits of the sour passion fruit hybrid (BRS Sol do Cerrado) and found $3.28 \mathrm{mg}^{100 \mathrm{~g}^{-1}}$ in conventional farming, a value lower than that found in the present study. This result is indicative that passion fruit residues have higher flavonoid concentrations than those of the pulp this fruit. 


\section{TABLE 2 - LEVELS OF BIOACTIVE PHYTOCHEMICAL EXTRACTS OF YELLOW PASSION}

FRUIT RESIDUE FLOUR EXPRESSED ON DRY WEIGHT BASIS.

\section{Bioactive phytochemical}

Yellow passion fruit residue flour
Total flavonoids ${ }^{2}\left(\mathrm{mg} .100 \mathrm{~g}^{-1}\right)$

Condensed tannins ${ }^{3}\left(\mathrm{mg} .100 \mathrm{~g}^{-1}\right)$
$23.87 \pm 0.03$

$0.31 \pm 0.15$

Total phenolic ${ }^{4}\left(\mathrm{mg} .100 \mathrm{~g}^{-1}\right)$

$24.87 \pm 0.18$

${ }^{4} \mathrm{mg}$ of gallic acid. $100 \mathrm{~g}^{-1}$

Studies on the determination of flavonoid content in passion fruit have focused on leaves and aerial plant parts (ZERAIK et al., 2010). Chabariberi et al. (2009) evaluated the flavonoid content in the leaves of Passiflora edulis and found $10.77 \mathrm{mg} \mathrm{g}^{-1}$ (expressed as mg rutin equivalent), a value higher than that found in the present study. The difference between these results can be attributed to losses during the residue dehydration and to the different standards used for quantification.

Flavonoids are secondary metabolites synthesized by plants belonging to the group of phenolic compounds, which are important due to their antioxidant activity against free radicals. These phytochemicals have potential biological activity related to the prevention of chronic diseases and highly beneficial effects to humans, especially their antioxidant, anti-inflammatory, antiulcerogenic, antihypertensive, antimicrobial, antiviral, anti-hepatotoxic, and antiplatelet activities (XIAO, CHEN and CAO, 2014; MORAES and COLA, 2006; PETERSON and DWYER, 1998).

The passion fruit residue flour prepared showed low content of condensed tannins. Analyzing Brazilian cerrado (savanna) native fruits, Rocha et al. (2011) found similar results for pitanga-docerrado (Eugenia punicifolia) (51 mg.100 g-1), pera-do-cerrado (Eugenia klotzchiana) (30 mg.100 g ${ }^{-1}$ ), and cagaita (Eugenia dysenterica) $\left(4 \mathrm{mg}^{1} 100 \mathrm{~g} \mathrm{~g}^{-1}\right)$; values expressed as $\mathrm{mg}$ catechin equivalents. Low tannin concentration in fruits is associated with desirable sensory attributes. On the other hand, the presence of high levels of tannins is associated to the undesirable astringency in some fruits, which is attributed to the precipitation of the glycoproteins leading to loss of saliva lubricity (MONTEIRO et al., 2005).

The total phenolic content found in the passion fruit residue flour was higher than that reported for other fruit residues, as those found by Sousa et al., (2011), who evaluated residue flour of tropical fruits such as pineapple (8.60 mg GAE.100g-1), soursop (18.60 mg GAE.100 $\left.\mathrm{g}^{-1}\right)$ and cupuaçu (Theobroma grandiflorum) (4.66 mg GAE. $\left.100 \mathrm{~g}^{-1}\right)$; results obtained using whole fruit residues (peel, seeds, and bagasse,) On the other hand, evaluating the phenolic content of tropical

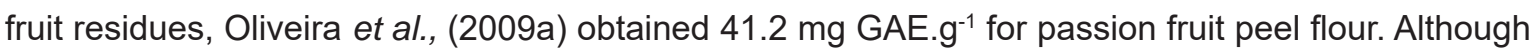
the total phenolic content found in the present study is lower than that reported by Oliveira et al. (2009a), it is worth mentioning that the residue used by these authors to obtain the extract consisted of endocarp and seeds. Several studies have reported that seeds have higher total phenolic content than the peel (BABBAR, OBEROI and PATIL, 2011; SOONG and BARLOW, 2004).

Fruits are important source of polyphenols, but the content of these phytochemicals, in both qualitative and quantitative terms, varies due to factors such as fruit part, processing characteristics, extraction methods, cultivar, variety, maturation stage, and edaphoclimatic conditions (MELO et al., 2008). Therefore, the different contents of total phenolic and carotenoid found may be associated with these factors and with the interaction between phytochemical fractions, which, in turn, may influence the content of these constituents in the food. 
It is important to note that the total phenolic content obtained may have been influenced by factors such as the presence of heterogeneous species of phenolic compounds and easily oxidized non-phenolic substances. Furthermore, the total phenolic content obtained by the Folin-Ciocalteu method underestimates the flavonoid content when gallic acid is used as standard (RAMIREZSANCHEZ et al., 2010; CHANDRA and MEJIA, 2004), which may have occurred in the present study.

The antioxidant efficacy of phenolic compounds depends on the chemical structure and concentration of these phytochemicals in the food (MELO et al., 2008). On the other hand, the analysis of bioactive compounds in plant materials is somewhat complex since it can be influenced by several different factors such as chemical characteristics of the compound, extraction method used, sample type and size, storage time and conditions, analysis method used, type of analytical standard used, and the presence interfering substances, such as waxes, fats, terpenes, and chlorophylls (NACZK and SHAHIDI, 2006).

With regard to the evaluation of the antioxidant efficacy of the hydroethanolic extract of the passion fruit residue flour evaluated by DPPH, its free radical-scavenging activity exceeded 60 $\%$ (Table 3). The value of the correlation coefficient between antioxidant activity and total phenolic content obtained by DPPH method (Figure 1) indicates that the flour analyzed has significant antioxidant capacity and is positively correlated with total phenolic content.

TABLE 3 - ANTIOXIDANT CAPACITY OF HYDROETHANOLIC EXTRACTS OF YELLOW PASSION FRUIT RESIDUE FLOUR BY DPPH AND ABTS METHODS.

\begin{tabular}{lcc}
\hline SAMPLE & $\begin{array}{c}\text { DPPH } \\
\text { (\% inhibition) }\end{array}$ & $\begin{array}{c}\text { ABTS } \\
\text { (mg VEAC. 100g-1) }\end{array}$ \\
\hline Passion fruit residue flour & 65.31 & 36.09 \\
\hline
\end{tabular}

${ }^{1}$ VEAC: ascorbic acid equivalent

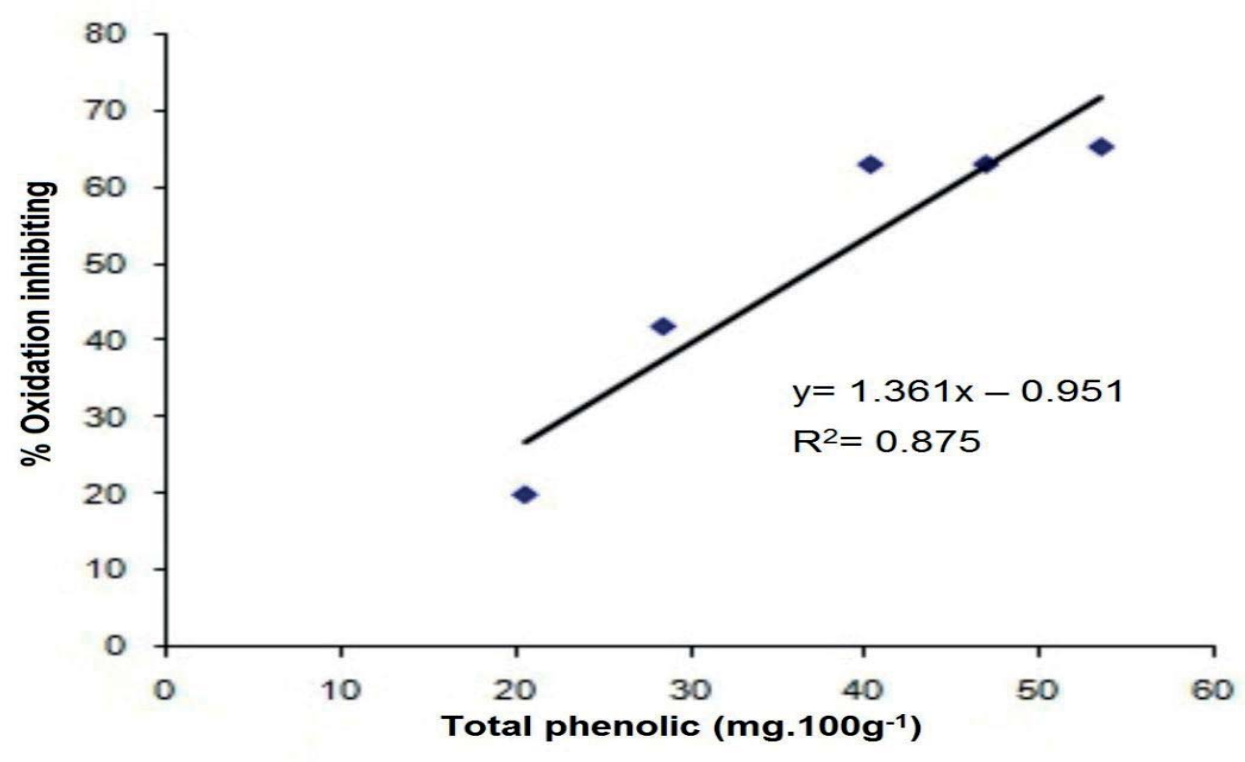

FIGURE 1. CORRELATION BETWEEN ANTIOXIDANT CAPACITY AND TOTAL PHENOLIC CONTENT OF THE EXTRACT OF PASSION FRUIT RESIDUE FLOUR (PASSIFLORA EDULIS F. FLAVICARPA) BY DPPH METHOD. 
Melo et al. (2008) evaluated the total phenolic content and antioxidant activity of frozen fruit pulps. These authors classified the samples that exhibited sequestration capacity of DPPH above $70 \%$, between 50 and $70 \%$, and below $50 \%$ as strong, moderate, and weak, respectively. In their study, the values found for pulps of cashew, guava, acerola (Malpighia glabra), grape, and mango stood out and were classified as strong. Therefore, according to Melo et al. (2008), the capacity of the passion fruit residue flour extract evaluated to sequester radicals DPPH can be classified as moderate.

With regard to the evaluation of antioxidant capacity by ABTS assay, it was found that

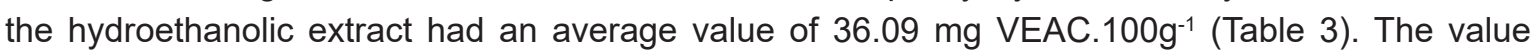
of the correlation coefficient between antioxidant activity and total phenolic content obtained by ABTS method indicates that the flour evaluated has significant antioxidant capacity and is positively correlated with total phenolic content.

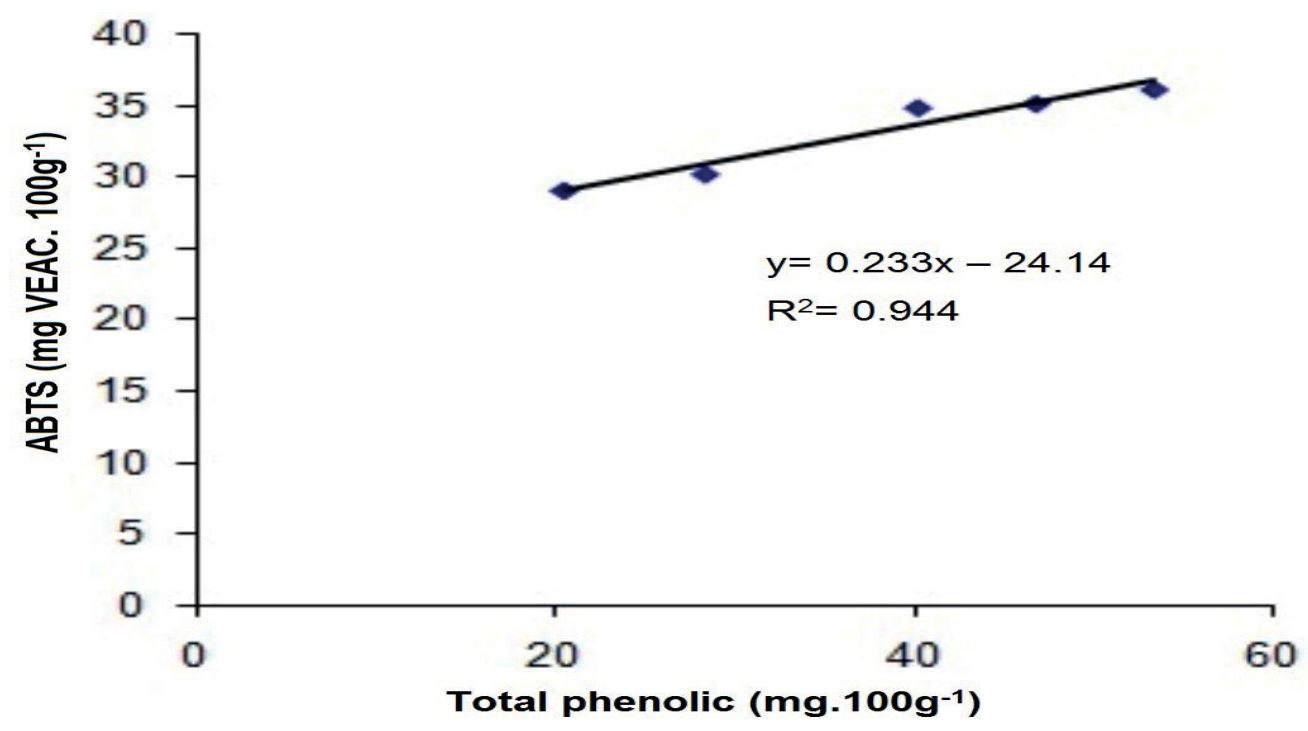

FIGURE 2. CORRELATION BETWEEN ANTIOXIDANT CAPACITY (VEAC) AND TOTAL PHENOLIC CONTENT OF THE EXTRACT OF YELLOW PASSION FRUIT RESIDUE FLOUR (PASSIFLORA EDULIS F. FLAVICARPA).

Several studies have demonstrated antioxidant potential by determining the total phenolic content and using antioxidant assays in a wide variety of plants. However, there are few studies on the antioxidant activity of fruit residues, especially passion fruit by-products. Additionally, it seems like there is no consensus among researchers regarding the evaluation of antioxidant activity.

Vasconcelos et al. (2011) argue for the total antioxidant capacity evaluation because of the difficulty in measuring each antioxidant component separately and their interaction in the plasma. On the other hand, Sies (2007) disagrees with this idea since he believes that dietary phytochemicals undergo different absorption processes and metabolism and due to the fact that enzymes act as antioxidants. Thus, this author believes that antioxidants should be assessed separately.

Since there is a lack of official standard method for evaluation of antioxidant activity and due to the diversity of the existing methods, it is necessary to carry out different specifically designed assays (PERTUZATTI et al., 2014; OLIVEIRA et al., 2009b).

Accordingly, further studies on the identification and quantification of phytochemicals in fruit residues, in addition to the evaluation of the antioxidant capacity of these by-products, are necessary to help the food industry develop food products with functional claims. 


\section{CONCLUSIONS}

The present study revealed the presence of condensed tannins, total flavonoids, and total phenolics in the Passiflora edulis f. flavicarpa residue flour. The passion fruit residue flour prepared showed significant antioxidant activity by the DPPH method, and there was a positive correlation between antioxidant activity and the total phenolic content according to both the DPPH radical scavenging method and the ABTS assay. Yellow passion fruit residue flour is a source of natural antioxidants with potential to be used in the food industry as an ingredient in the development of food products with functional claims.

\section{RESUMO}

\section{AVALIAÇÃO FITOQUÍMICA E ANTIOXIDANTE DO EXTRATO HIDROETANÓLICO DOS RESÍDUOS DE PASSIFLORA EDULIS F. FLAVICARPA}

A maioria dos resíduos frutícolas é apontada como sendo rica em fitoquímicos bioativos, tais como polifenóis (antioxidantes naturais), responsáveis por grandes benefícios à saúde quando ingeridos regularmente, atuando na prevenção de doenças degenerativas. Objetivou-se com este trabalho determinar a composição fitoquímica (taninos condensados, flavonoides totais e fenólicos totais) e avaliar a capacidade antioxidante (ensaios DPPH e ABTS) da farinha de resíduos de maracujá-amarelo, constituídos de epicarpo e mesocarpo, provenientes de indústrias processadoras de polpas de frutas. Os resíduos de maracujá foram submetidos a tratamento térmico pelo método de secagem em estufa com circulação e renovação de ar e processados para a obtenção de farinha. A composição fitoquímica apresentou os seguintes teores: taninos condensados: 0,31 mg.100 g-1; flavonoides totais: $23,87 \mathrm{mg} .100 \mathrm{~g}-1$ e fenólicos totais: $24,87 \mathrm{mg} .100 \mathrm{~g}-1$. A farinha de resíduos de maracujá-amarelo apresenta capacidade antioxidante expressiva pelo ensaio do DPPH e correlaciona-se de forma positiva com o conteúdo de fenólicos totais, tanto pelo ensaio do ABTS quanto pelo método do radical DPPH. A farinha de resíduos de maracujá-amarelo constitui uma fonte de antioxidantes naturais com potencial para ser utilizada pela indústria de alimentos como ingrediente na elaboração de produtos alimentícios com alegações funcionais.

PALAVRAS-CHAVE: MARACUJÁ-AMARELO; RESÍDUO; CAPACIDADE ANTIOXIDANTE; DPPH; ABTS.

\section{REFERENCES}

1 ABUD, A. K. S.; NARAIN, N. Incorporação da farinha de resíduo do processamento de polpa de fruta em biscoitos: uma alternativa de combate ao desperdício. Brazilian Journal Food Technology, v. 12, n. 4, p. 257-265, Oct./Dec. 2009.

2 BABBAR, N.; OBEROI, D. S.; PATIL, R. T. Total phenolic content and antioxidant capacity of extracts obtained from six important fruit residues. Food Research International, v. 44, n. 1, p. 391-396, Jan. 2011.

3 BRAND-WILLIAMS, W.; CUVELIER, M.E.; BERSET, C. Use of a free radical method to evaluate antioxidant activity. Lebensmittel Wissenschaft und Technologie - Food Science and Technology, v. 28, p. 25-30, 1995.

4 CHABARIBERI, R. A. O.; POZZI, A. C. S.; ZERAIK, M. L.; YARIWAKE, J. H. Determinação espectrométrica dos flavonóides das Folhas de Maytenus (Celastraceae) e de Passiflora (Passifloraceae) e comparação com o Método CLAE-UV. Revista Brasileira de Farmacognosia, v.19, n. 4, p 860-864, Oct./Dec. 2009.

5 CHANDRA, S.; DE MEJIA, E. G. Polyphenolic compounds, antioxidant capacity, and quinone reductase activity of an aqueous extract of Ardisia compressa in comparison to mate (llex paraguariensis) and green (Camellia sinensis) teas. Journal of Agricultural and Food Chemistry, v. 52, n. 11, p. 3583-3589, June 2004.

6 COHEN, K. O.; COSTA, A. M.; TUPINAMBÁ, D. D.; JUNQUEIRA, N. T. V.; FALEIRO, F. G.; BAIOCCHI, M. DO V.; SOUSA, H. N. Compostos funcionais na polpa de frutos do híbrido de maracujazeiro azedo BRS Sol do Cerrado. EMBRAPA CERRADOS, Planaltina - DF, Comunicado Técnico 157, Dec. 2008. 
7 DHILLON, G. S.; KAUR, S.; BRAR S. K. Perspective of apple processing wastes as low-cost substrates for bioproduction of high value products: A review. Renewable and sustainable energy reviews, v. 27, p. 789-805, Nov. 2013.

8 EMBRAPA. Processamento mínimo de frutas e hortaliças: tecnologia, qualidade e sistemas de embalagem. Sérgio Agostinho Cenci - Rio de Janeiro: Embrapa Agroindústria de Alimentos, 2011. 144p.

9 EMBRAPA. Mandioca e Fruticultura. Produção brasileira de maracujá em 2012. Fev. 2014. Disponível em: <http://www. cnpmf.embrapa.br/planilhas/Maracuja_Brasil_2012.pdf>. Acesso em: 02 abr. 2014.

10 HAMINIUK, C. W.; MACIEL, G. M.; PLATA-OCIEDO, M. S. V.; PERALTA, R. M. Phenolic compounds in fruits - an overview. International Journal of Food Science and Technology, v. 47, n. 2, p. 2023-2044, July 2012.

11 JORGE, N.; MALACRIDA, C. R.; ANGELO, P. M.; ANDREO, D. Composição centesimal e atividade antioxidante do extrato de sementes de maracujá (passiflora edulis) em óleo de soja. Revista Pesquisa Agropecuária Tropical, v. 39, n. 4, p. 380-385, Dec. 2009.

12 KOBORI, C. N.; JORGE, N. Caracterização dos óleos de algumas sementes de frutas como aproveitamento de resíduos industriais. Ciência Agrotécnica, v. 29, n. 5, p. 1008-1014, Sept./Oct. 2005

13 MARINOVA, D.; RIBAROVA, F.; ATANASSOVA, M.; Total phenolics and total flavonoids in Bulgarian fruits and vegetables. Journal of the University Chemical Technology and Metallurgic, v. 40, n. 3, p. 255 - 260, 2005.

14 MELETTI, L. M. M. Avanços na cultura do maracujá no Brasil. Revista Brasileira de Fruticultura, v. 33, n.spe1, p. 83-91, Oct. 2011.

15 MELO, E. DE A.; MACIEL, M. I. S.; LIMA, V. L. A. G. DE; ARAÚJO, C. R. DE. Teor de fenólicos totais e capacidade antioxidante de polpas congeladas de frutas. Alimentos e Nutrição, v.19, n.1, p. 67-72, Jan./Mar. 2008.

16 MONTEIRO, J. M.; ALBUQUERQUE, U. P.; ARAÚJO, E. L.; AMORIM, E. L. C. Taninos: uma abordagem da química à ecologia. Química Nova, v. 28, n. 5, p. 892-896, Sept./Oct. 2005.

17 MORAES, F. P.; COLLA, L. M. Alimentos funcionais e nutracêuticos: definições, Legislação e benefícios à saúde. Revista Eletrônica de Farmácia, v. 3, n. 2, p. 109-122, 2006.

18 NACZK, M.; SHAHIDI, F. Phenolics in cereals, fruits and vegetables: occurrence, extraction and analysis. Journal Pharmaceutical and Biomedical Analysis, v. 41, n. 5, p. 1523-1542, Nov. 2006.

19 NAGEL, A.; NEIDHART, S; ANDERS, T.; ELSTNER, P.; KORHUMMEL, S.; SULZER, T.; WULFKÜHLER, S.; WINKLER, C; QADRI, S.; RENTSCHLER, C.; PHOLPIPATTANAPONG, N.; WUTHISOMBOON, J.; ENDRESS, H.; SRUAMSIRI, P.; CARLE, R. Improved processes for the conversion of mango peel into storable starting material for the recovery of functional co-products. Industrial Crops and products, v. 61, p. 92-105, Nov. 2014.

20 OLIVEIRA, A. C. DE; VALENTIM, I. B.; SILVA, C. A.; BECHARA, E. J. H.; BARROS, M. P. DE; MANO, C. M.; GOULART, M. O. F. Total phenolic content and free radical scavenging activities of methanolic extract powders of tropical fruit residues. Food Chemistry, v. 115, n. 2, p. 469-475, July 2009a.

21 OLIVEIRA, A. C. DE; VALENTIM, I. B.; GOULART, M. O. F.; SILVA, C. A.; BECHARA, E. J. H.; TREVISAN, M. T. S. Fontes vegetais naturais de antioxidantes. Química Nova, v. 32, n. 3, p. 689-702, Apr. 2009b.

22 OLIVEIRA, L. F.; NASCIMENTO, M. R. F.; BORGES, S. V.; RIBEIRO, P. C. N.; RUBACK, V. R. Aproveitamento alternativo da casca do maracujá-amarelo (Passiflora edulis f. flavicarpa) para produção de doce em calda. Ciência e Tecnologia de Alimentos, v. 22, n. 3, p. 259-62, Sept./Dec. 2002.

23 PERTUZATTI, P. B.; BARCIA, M. T.; RODRIGUES, D.; CRUZ, P. N.; HERMOSÍN-GUTIÉRREZ, I.; SMITH, R.; GODOY, H. T. Antioxidant activity of hydrophilic and lipophilic extracts of Brazilian blueberries. Food Chemistry, v.164, p. 81-88, Dec. 2014.

24 PETERSON, J.; DWYER, J. Flavonoids: dietary occurrence and biochemical activity. Nutrition Research, v. 18, n. 12, p. 1995-2018, Dec. 1998.

25 PORTER, L. J.; HRSTICH, L. N., CHAN, B. G. The conversion of procyanidins and prodelphinidins to cyaniding and delphinidin. Phytochemistry, v. 25, [s/n], p. 223-230, Dec. 1986.

26 RAMIREZ-SANCHEZ, I.; MAYA, L.; CEBALLOS, G.; VILARREAL, F.; Fluorescent detection of (-)-epicatechin in microsamples from cacao seeds and cocoa products: comparison with Folin-Ciocalteu method. Journal of Food Composition Analysis, v. 23, n. 8, p. 790-793, Dec. 2010.

27 RE, R.; PELLEGRINI, N.; PROTEGgENTE, A.; PANNALA, A.; YANG, M.; RICEEVANS, C. Antioxidant activity applying an improved ABTS radical cation decolorization assay. Free Radical Biology and Medicine, v. 26, n. 9-10, p. 1231-1237, May 1999.

28 ROCHA, W. S.; LOPES, R. M.; SILVA, D. B. DA; VIEIRA, R. F.; SILVA, J. P. DA; AGOSTINI-COSTA, T. DA S. Compostos fenólicos totais e taninos condensados em frutas nativas do cerrado. Revista Brasileira de Fruticultura, v. 33, n. 4, p. 1215-1221, Dec. 2011. 
29 SIES, H. Total antioxidant capacity: appraisal of a concept. The Journal of Nutrition, v. 137, n. 6, p. 1493-1495, June 2007.

30 SOONG, Y.; BARLOW, P. L. Antioxidant activity and phenolic content of selected fruit seeds. Food Chemistry, v. 88, p.411417, Dec. 2004.

31 SOUSA, M. S. B.; VIEIRA, L. M., SILVA, M. DE J. M. DA; LIMA, A. DE. Caracterização nutricional e compostos antioxidantes em resíduos de polpas de frutas tropicais. Ciência e Agrotecnologia, v. 35, n. 3, p. 554-559, May/June 2011.

32 VASCONCELOS, S. M. L.; SILVA, M. A. M.; BENFATO, M. S.; RABELO, L. A.; FONTES, G. Marcadores de desequilíbrio redox em sangue de pacientes hipertensos de uma comunidade no Nordeste do Brasil. Arquivos Brasileiros de Cardiologia, v. 97, n. 2, p. 141-147, Aug. 2011.

33 WETTASINGHE, M.; SHAHIDI, F. Evening Primrose Meal: A Source of Natural Antioxidants and Scavenger of Hydrogen Peroxide and Oxygen-Derived Free Radicals. Journal of Agricultural and Food Chemistry, v. 47, n. 5, p. 1801-1812, May 1999.

34 WOISKY, R. G.; SALATINO, A. Analysis of propolis: some parameters and procedures. Journal of Apicultural Research, v. 37, n. 2, p. 99-105, June 1998.

35 XIAO, J.; CHEN, T.; CAO, H. Flavonoid glycosylation and biological benefits, Biotechnology Advances, v. 32, n. 6, p. 11451156, May 2014.

36 ZERAIK, M. L.; YARIWAKE, J. H. Quantification of isoorientin and total flavonoids in Passiflora edulis fruit pulp by HPLCUV/DAD. Microchemical Journal, v. 96, n. 1, p. 86-91, Sept. 2010.

37 ZERAIK, M. L.; PEREIRA, C. A. M.; ZUIN, V. G.; YARIWAKE, J. H. Maracujá: um alimento funcional? Revista Brasileira de Farmacognosia, v. 20, n. 3, p. 459-471, June/July 2010.

38 ZHAO, B.; HALL, C. A. Composition and antioxidant activity of raisin extracts obtained from various solvents. Food Chemistry, v. 108, n. 2, p. 511-518, May 2008.

\section{ACKNOWLEDGMENTS}

The authors wish to thank the pulp processing industries fruit Frutar (Vitoria da Conquista, Bahia) and Nutrical (Ibirataia, Bahia) for providing the samples used. 